\title{
OD BIBLIOTEKI BRAJLOWSKIEJ DO CYFROWEJ, CZYLI O MATERIAŁACH ALTERNATYWNYCH I TECHNOLOGIACH WSPOMAGAJĄCYCH DLA UŻYTKOWNIKÓW Z NIEPEŁNOSPRAWNOŚCIĄ WZROKU. W KRĘGU ROZWAŻAŃ BIBLIOLOGICZNO-TYFLOLOGICZNYCH
}

Źródła informacji i technologie informacyjno-komunikacyjne w zapisach prawnych. Kognitywny proces zachowania się użytkownika z niepełnosprawnością wzroku. Materiały alternatywne i technologie wspomagające we współczesnej bibliotece. Zastosowanie technologii cyfrowych w bibliotekach dla niewidomych w Polsce.

SŁOWA KLUCZOWE: osoba z niepełnosprawnością wzroku, biblioteki dla niewidomych, materiały w formatach alternatywnych, technologie wspomagające, system Braille'a, tyflografika, audiodeskrypcja

\section{WPROWADZENIE}

Społeczeństwo informacyjne, wyznaczające zasady psychospołecznego (a nie tylko informacyjnego) funkcjonowania człowieka, cechuje się własną stratyfikacją i generuje grupy wykluczenia cyfrowego, ściśle powiązanego z wykluczeniem społecznym. Dominik Batorski wykluczenie cyfrowe (e-wykluczenie) rozumie bowiem jako „różnice między tymi, którzy mają regularny dostęp do technologii cyfrowo-informacyjnych i potrafią efektywnie z nich korzystać, a tymi, którzy tego dostępu i umiejętności nie mają"1. Wykluczenie społeczne jest sytuacją uniemożliwiającą lub utrudniającą ,jednostce lub grupie, zgodne z prawem pełnienie ról społecznych, korzystanie z dóbr publicznych i infrastruktury społecznej, gro-

${ }^{1}$ D. Batorski, Wykluczenie cyfrowe w Polsce, ,Studia Biura Analiz Sejmowych Kancelarii Sejmu" 2009, nr 3 (19), s. 225-226. 
madzenie zasobów i zdobywanie dochodów w godny sposób" ${ }^{2}$. Wśród wykluczonych społecznie i cyfrowo wymienia się m.in. osoby z niepełnosprawnością wzroku, przez bibliotekoznawców określane jako osoby z trudnościami w odczytywaniu druku (people with print disabilities lub print disabled).

Tymczasem nowe technologie osobom z niepełnosprawnością wzroku ewidentnie poszerzają dostęp do informacji, przeobrażając ,,jakościowo" ich, powodowaną dysfunkcją sensoryczną, niesprawność czytelniczą. Wprowadzają ich do kultury informacji, za Małgorzatą Kisilowską rozumianej jako „sposób świadomego i aktywnego funkcjonowania człowieka w przestrzeni informacyjnej oraz jego konsekwencje"3. Warunkami kształtowania się kultury informacji są indywidualne kompetencje informacyjne oraz środowisko informacyjne, czyli otoczenie, do funkcjonowania w którym wzmiankowane kompetencje są niezbędne. Kompetencje informacyjne wyznaczają człowiekowi (w tym z niepełnosprawnością wzroku) miejsce w stratyfikacji społeczeństwa informacyjnego, lokując go w klasie proletariatu, kogitariatu lub dygitariatu ${ }^{4}$.

Biblioteka wskazywana jest jako instytucja kształtująca kulturę informacyjną, a tym samym zapobiegająca wykluczeniu cyfrowemu i społecznemu osób z niepełnosprawnością wzroku. Dzięki wyposażeniu w materiały alternatywne i technologie wspomagające może przyczynić się do zajęcia przez niepełnosprawnych wzrokowo użytkowników miejsca w klasie dygitariatu.

Problem ten nie znalazł dotąd należnego miejsca ani w rozważaniach bibliologiczno-informatologicznych, ani w tyflologicznych, czego dowodzi ciągle skromna literatura przedmiotu. Stąd znaczące wydają się tu (wymienione chronologicznie) publikacje pod redakcją i autorskie Małgorzaty Czerwińskiej i Teresy Dederko, Małgorzaty Fedorowicz i Magdaleny J. Cyrklaff oraz Małgorzaty Paplińskiej ${ }^{5}$.

Dociekania badawcze (m.in. analiza dokumentów) i wieloletnia obserwacja uczestnicząca autorki niniejszych rozważań każą postrzegać niezmienną aktualność zagadnienia uwarunkowań wypełniania wobec użytkowników z niepełnosprawnością przez współczesną bibliotekę funkcji: informacyjnej, edukacyjnej, intelektualnej, rozrywkowej, substytutywnej ${ }^{6}$. Ich realizacja (warunkowana dys-

2 Narodowa Strategia Integracji Społecznej dla Polski, Ministerstwo Polityki Społecznej, Zespół Zadaniowy ds. Reintegracji Społecznej, Warszawa 2004, s. 23, https://www.mpips.gov.pl/ userfiles/File/mps/NSIS.pdf [dostęp: 15.11.2017].

3 M. Kisilowska, Kultura informacji, Warszawa 2016, s. 42.

4 R. Tadeusiewicz, Społeczność Internetu, Warszawa 2002, s. 285.

5 Niewidomi w świecie książek i bibliotek. Wybrane zagadnienia, pod red. M. Czerwińskiej, T. Dederko, Kielce 2008, passim; M. Fedorowicz, Człowiek niepetnosprawny w bibliotece publicznej, Torun 2010, passim; M. Fedorowicz-Kruszewska, M.J. Cyrklaff, Media w środowisku osób zagrożonych wykluczeniem społecznym, Toruń 2016, passim; Pismo Braille'a. Z tradycja w nowoczesność, pod red. M. Paplińskiej, Warszawa 2016, passim.

6 J. Wojciechowski, Uwagi o typologii bibliotek, „Biblioteka” 2001, nr 5, s. 109-122. 
ponowaniem zasobami w formatach alternatywnych, dostosowanymi pod względem wydawniczo-formalnym do specyfiki percepcji tych osób (accessible document), i technologiami wspomagającymi (assistive technology), ułatwiającymi lub wręcz umożliwiającymi dostęp do informacji, zwłaszcza za pomocą komputera i Internetu) czyni bibliotekę miejscem kontaktu osób niepełnosprawnych wzrokowo z edukacją, nauką, kulturą — odbywającego się w duchu integracji (inkluzji) społecznej?.

Stąd też rozważania niniejsze koncentrują się wokół specyfiki i znaczenia współczesnych materiałów alternatywnych i technologii wspomagających dla komunikacji społecznej osób niepełnosprawnych wzrokowo, a tym samym roli bibliotek w kształtowaniu ich kultury informacyjnej i czytelniczej.

\section{ŹRÓDŁA INFORMACJI I TECHNOLOGIE INFORMACYJNO-KOMUNIKACYJNE W ZAPISACH PRAWNYCH}

Funkcjonowanie bibliotek dla niewidomych, obsługę biblioteczno-informacyjną użytkowników niesprawnych czytelniczo, dostęp do informacji osób z niepełnosprawnością (w tym z niepełnosprawnością wzroku) reguluje wiele międzynarodowych i krajowych aktów prawnych, ogólnych i resortowych (np. wytyczne International Federation of Library Associations and Institutions - IFLA) ${ }^{8}$.

Zasadne wydaje się przywołanie tu wybranych artykułów Konwencji Praw Osób Niepełnosprawnych Narodów Zjednoczonych, ustanowionej w 2006 roku, a ratyfikowanej przez Polskę w 2012. Art. 2 definiuje pojęcie komunikacji, uznając, że oznacza ona języki, tekst wyświetlany, alfabet Braille’a, komunikację dotykową, duży druk, dostępne multimedia, jak również środki przekazu: pisane, słuchowe, wyrażane prostym i zrozumiałym językiem, czytane przez lektora oraz wspomagające i alternatywne sposoby komunikacji, środki i formaty, łącznie z dostępną technologią informacyjną i komunikacyjną. Art. 9 zobowiązuje do działań na rzecz dostępności dla osób niepełnosprawnych, na równych zasadach z innymi obywatelami, środowiska fizycznego, transportu, informacji i komunikacji międzyludzkiej, w tym technologii i systemów komunikacyjnych i informacyjnych oraz innych udogodnień i usług (m.in. informacyjnych, komunikacyjnych, elektronicznych), poprzez m.in.: zapewnienie oznakowania w alfabecie Braille'a oraz

${ }^{7}$ D. Grygrowski, Funkcje nowoczesnej biblioteki w spoleczeństwie wiedzy, [w:] Nowoczesna biblioteka, pod red. M. Drzewieckiego, Warszawa 2009, s. 9-20.

${ }^{8}$ Libraries for the Blind in the Information Age - Guidelines for development, pod red. R. Kavanagh, B. Christensen Sköld, International Federation of Library Associations and Institutions, IFLA Professional Reports, nr 86, The Hague 2005, http://www.ifla.org/files/assets/hq/publications/professional-report/86.pdf [dostęp: 20.11.2017]; Guidelines for Library Service to Braille Users, IFLA [serwis internetowy], http://www.ifla.org/publications/guidelines-for-library-serviceto-braille-users [dostęp: 20.11.2017]. 
w formie łatwej do czytania i zrozumienia w budynkach i innych obiektach publicznych, zapewnienie pomocy ze strony innych osób i pośredników (np. przewodników, lektorów), promowanie dostępu do najnowszych technologii oraz systemów informacyjno-komunikacyjnych, w tym do Internetu. Art. 21, odnoszący się do wolności wypowiedzi i swobody wyrażania poglądów oraz dostępu do informacji, zaleca m.in.: dostarczanie osobom niepełnosprawnym informacji przeznaczonych dla ogółu społeczeństwa w dostępnym formacie i za pomocą środków przekazu odpowiednich do rodzaju niepełnosprawności, bez opóźnień i dodatkowych kosztów; akceptowanie i umożliwienie korzystania w sytuacjach oficjalnych z pisma Braille'a, wspomagających i alternatywnych sposobów komunikacji oraz wszelkich innych środków, sposobów i formatów komunikacji wybranych przez osoby niepełnosprawne; nakłanianie prywatnych usługodawców świadczących usługi dla ogółu społeczeństwa, w tym dostawców usług internetowych, do dostarczania informacji i usług w formie dostępnej dla osób niepełnosprawnych; zachęcanie środków masowego przekazu, w tym dostawców informacji poprzez Internet, do udostępniania swoich usług osobom niepełnosprawnym. Art. 24, poświęcony prawu do edukacji włączającej, zaleca m.in.: umożliwienie nauki alfabetu Braille’a, pisma alternatywnego, stosowanie powiększonego druku, wspomagających i alternatywnych sposobów, środków i formatów komunikacji. Art. 30 podnosi prawo do uczestniczenia w życiu kulturalnym, zapewniane m.in. poprzez: korzystanie z materiałów dotyczących zagadnień kultury w dostępnych formatach, dostęp do programów telewizyjnych, filmów, teatru i innych form działalności kulturalnej w dostępnych formatach, zapewnienie, aby akty prawne dotyczące ochrony praw własności intelektualnej nie stanowiły nieracjonalnej bariery dyskryminującej osoby niepełnosprawne w dostępie do materiałów związanych ze sferą kultury ${ }^{9}$.

Szansą na szerokie udostępnienie publikacji książkowych i prasy jest traktat z Marrakeszu o ułatwieniu dostępu do opublikowanych utworów osobom niewidomym, słabowidzącym i osobom z niepełnosprawnościami uniemożliwiającymi zapoznawanie się z drukiem. Wypracowany on został przez Światową Organizację Własności Intelektualnej (agenda ONZ), ogłoszony w 2013 roku i podpisany przez stronę polską w 2014. Jego celem jest ustanowienie międzynarodowego standardu korzystania przez osoby z niepełnosprawnością z utworów publikowanych w postaci druku i pozostających pod ochroną prawa (pozwolenie na wytwarzanie i upowszechnianie publikacji w wersjach alternatywnych) ${ }^{10}$.

${ }^{9}$ Konwencja o prawach osób niepełnosprawnych — przyjęta przez Zgromadzenie Ogólne Narodów Zjednoczonych 13 grudnia 2006 roku, podpisana przez Polskę 30 marca 2007 roku, ratyfikowana 6 września 2012 roku, Dz.U. z 2012, poz. 1169, http://isap.sejm.gov.pl/DetailsServlet?i d=WDU20120001169 [dostęp: 20.11.2017].

10 Traktat z Marrakeszu, http://www.prawoautorskie.gov.pl/.../Traktat_z_Marrakeszu_polska_wersja_jezykowa_finalna.pdf [dostęp: 20.11.2017]. 
Zasadność postanowień traktatu została potwierdzona zapisami rezolucji, zwiększającymi dostęp osób niewidomych i słabowidzących do publikacji drukowanych, wydanymi przez Komisję ds. Konstytucyjnych (AFCO) Parlamentu Europejskiego w 2017 roku$^{11}$.

Dostępnością Internetu dla osób z niepełnosprawnością od 1994 roku zajmuje się World Wide Web Consortium (W3C) - zrzeszenie ponad 400 organizacji, firm, agencji rządowych i uczelni z całego świata. Wypracowane przez nie standardy stały się podstawą regulacji prawnych w wielu krajach, w tym także w Polsce. Od 2008 roku obowiązuje, opracowany przez Web Accessibility Initiative (WAI), międzynarodowy standard WCAG 2.0 (Web Content Accessibility Guidelines), wraz z dokumentami uzupełniającymi: Understanding WCAG, Techniques for $\mathrm{WCAG}^{12}$.

Kwestia korzystania przez osoby niepełnosprawne z chronionych prawem utworów na zasadzie dozwolonego użytku jest uregulowana w Polsce w art. 331 ustawy z dnia 4 lutego 1994 roku o prawie autorskim i prawach pokrewnych ${ }^{13}$. Zapis ten stanowi podstawę prawną wytwarzania i upowszechniania publikacji w formatach alternatywnych, a więc jest istotny zarówno dla wydawców, jak i bibliotek.

W Polsce proces regulacji dostępności stron internetowych rozpoczął się w 2010 roku od przyjęcia nowelizacji ustawy o informatyzacji działalności podmiotów realizujących zadania publiczne. Zawarto w niej zobowiązanie do określenia sposobu udostępniania treści niepełnosprawnym obywatelom. Stosowne zapisy znajdują się również w Rozporządzeniu Rady Ministrów z dnia 12 kwietnia 2012 roku w sprawie Krajowych Ram Interoperacyjności, minimalnych wymagań dla rejestrów publicznych i wymiany informacji w postaci elektronicznej oraz minimalnych wymagań dla systemów teleinformatycznych. Rozporządzenie nakłada na wszystkie instytucje publiczne oraz jednostki realizujące działania publiczne

${ }^{11}$ Rezolucja Komisji ds. konstytucyjnych (AFCO) Parlamentu Europejskiego, www.rynekzdrowia.pl/.../Komisja-PE-za-lepszym-dostepem-do-ksiazek-i-prasy-dla-niewidomych-i-slabowidzacych,171370,14.html [dostęp: 5.05.2017].

12 Dostępne strony. Dostępność serwisów internetowych - podręcznik na temat dobrych rozwiązań w projektowaniu dostępnych serwisów internetowych dla osób z różnymi rodzajami niepetnosprawności, oprac. D. Paszkiewicz, Warszawa 2011, s. 8, http://dostepnestrony.pl/wp-content/ uploads/2012/02/Dostepnosc_serwisow_internetowych-PODRECZNIK11.pdf [dostęp: 20.11.2017]; D. Paszkiewicz, J. Dębski, Dostępność serwisów internetowych. Dobre praktyki w projektowaniu serwisów internetowych dostępnych dla osób z różnymi rodzajami niepetnosprawności, Warszawa 2013; Dostępność witryn internetowych instytucji publicznych dla osób niepetnosprawnych. Ocena zgodności z międzynarodowym standardem WCAG 2.0 oraz polskimi regulacjami prawnymi, pod red. M. Dziwisza, P. Witka, Kraków 2013.

13 Ustawa o prawie autorskim i prawach pokrewnych, Dz.U. z 2006 r., Nr 90, poz. 631, z późn. zm., http://www.prawo.sejm.gov.pl/isap.nsf/DocDetails.xsp?id=WDU19940240083 [dostęp: 20.11.2017]. 
obowiązek zagwarantowania dostępności swoich stron internetowych do końca 2015 roku na poziomie AA wytycznych WCAG $2.0^{14}$.

Raporty alternatywne organizacji pozarządowych, monitorowanie i audyty organizacji zrzeszonych w Forum Dostępnej Cyberprzestrzeni (np. Fundacja „Widzialni”), a także doświadczenia autorki wskazują na niską znajomość wzmiankowanych uregulowań przez zleceniodawców i twórców stron internetowych. Przestrzeń informacyjną osób z niepełnosprawnością wzroku w Polsce cechuje zatem: nieprzestrzeganie standardów WCAG 2.0. przy tworzeniu stron internetowych, dominacja papierowego obiegu dokumentów zapisanych w tradycyjnym druku (tzw. czarnodrukowych), znikoma liczba programów telewizyjnych i filmów z audiodeskrypcją, niedostateczne wyposażenie szkół ogólnodostępnych, instytucji kultury (w tym bibliotek) w technologie wspomagające, brak właściwych kompetencji pracowników instytucji kultury (w tym bibliotekarzy), nauczycieli szkół ogólnodostępnych do pracy w zakresie obsługi biblioteczno-informacyjnej, animacji kulturalnej i edukacji osób z niepełnosprawnością wzroku z wykorzystaniem wydawnictw alternatywnych i technologii wspomagających, znikome wykorzystanie nowych technologii (np. tyflografika, audiodeskrypcja) w udostępnianiu dóbr kultury, nieprzestrzeganie przez wydawców zaleceń odnoszących się do udostępniania publikacji $\mathrm{w}$ formatach alternatywnych ${ }^{15}$. Zauważa się ciągle ograniczoną dostępność bibliotek cyfrowych, powodowaną niedostosowaniem witryn internetowych, oprogramowania oraz formatów zasobów do obsługi przez osoby niepełnosprawne wzrokowo.

\section{KOGNITYWNY PROCES ZACHOWANIA SIĘ UŻYTKOWNIKA Z NIEPEŁNOSPRAWNOŚCIĄ WZROKU}

Efektywność obsługi biblioteczno-informacyjnej użytkowników z niepełnosprawnością wzroku (w tym trafność doboru materiałów alternatywnych i technologii wspomagających) warunkowana jest wiedzą tyflopsychologiczną na temat specyfiki procesów poznawczych osób z dysfunkcją wzroku.

14 Rozporządzenie Rady Ministrów z dnia 12 kwietnia 2012 roku w sprawie Krajowych Ram Interoperacyjności, minimalnych wymagań dla rejestrów publicznych i wymiany informacji w postaci elektronicznej oraz minimalnych wymagań dla systemów teleinformatycznych, www. dziennikustaw.gov.pl/du/2012/526/D2012000052601.pdf [dostęp: 5.05.2017].

15 Na przykład: http://www.kulturaslepych.farbb.com/ [dostęp: 7.05.2017]; Wykorzystanie technologii informacyjno-komunikacyjnych $w$ aktywizacji osób niepetnosprawnych, pod red. B. Mioduszewskiego, Warszawa 2013, passim; Spoleczny Raport Alternatywny z realizacji Konwencji o prawach osób z niepetnosprawnościami w Polsce, pod red. J. Zadrożnego, Warszawa 2015, passim. 
Brak wzroku (ślepota) w koncepcji „utrat” Thomasa J. Carrolla prowadzi m.in. do utraty łatwości porozumiewania się za pomocą pisma, utraty łatwości zdobywania informacji ${ }^{16}$.

Procesy poznawcze wzmiankowanych osób cechują się polisensorycznym sposobem postrzegania złożonym z bodźców: dotykowych, słuchowych, węchowych, smakowych; kompensacją poznawczą (kognitywną) na poziomie sensorycznym i percepcyjnym - tłumaczoną teorią tworzenia się dynamicznych układów strukturalnych w obrębie I i II układu sygnałowego ${ }^{17}$; dotykowymi i polisensorycznymi schematami poznawczymi; wyobrażeniami surogatowymi; poznawczą i kompensacyjną rolą języka (mowy) ${ }^{18}$.

Podstawowymi „kanałami informacyjnymi” są dotyk i słuch. Dotyk, co ma szczególne znaczenie dla posługiwania się systemem Braille’a i tyflografiką, nie ma łatwości wzroku w percypowaniu linii ciągłej, gdyż jest zmysłem wrażeń przerywanych. Percepcja dotykowa powierzchni jest trudniejsza niż punktów wypukłych. Zakres uwagi jest ograniczony: liczba elementów prostych, percypowanych w jednym akcie postrzegania, nie może przekroczyć sześciu. Łatwiej postrzegane są wrażenia uporządkowane niż bezładne. Dotyk pozwala poznać wielkość i kształt (niedokładnie), jest zmysłem sekwencyjnym (wrażeń sukcesywnych) i tzw. kontaktozmysłem (zmysł bliskonośny) — detekcyjnym, skórnym (obok zmysłu temperatury i bólu). Dzieli się na bierny i czynny (zmysł dotykowo-ruchowy), dzięki czemu pozwala na odbiór cech przedmiotu: szorstkość, gładkość, elementarne cechy przestrzenne (długość, szerokość, wysokość, kierunek), wielkość i kształt ${ }^{19}$.

Równie istotne znaczenie poznawcze ma zmysł słuchu: służy lokalizacji dźwięku, wspomaga rozwój mowy, jest źródłem informacji (instrukcji) słownej, umożliwia doznania estetyczne. Pozyskiwanie informacji przez osoby z głęboką niepełnosprawnością wzroku ma zatem charakter haptyczno-akustyczny (dotykowo-kinestetyczny i dźwiękowo-werbalny). Przekład intersemiotyczny informacji wzrokowych na dotykowe, słuchowe, polisensoryczne staje się przede wszystkim doświadczeniem poznawczym (przekazem informacyjnym), a następnie (choć nie zawsze) estetycznym.

Nakreślone tu uwarunkowania poznawcze są powodem trudności z odbiorem, przetwarzaniem i efektywnym wykorzystywaniem informacji. Rodzą tym samym potrzebę stosowania materiałów $\mathrm{w}$ formatach alternatywnych i technologii wspomagających.

16 Th.J. Carroll, Ślepota, czym jest, jakie sa jej skutki i jak żyć, będąc niewidomym, Warszawa 1972 .

17 M. Grzegorzewska, Wybór pism, Warszawa 1964.

18 T. Majewski, Tyflopsychologia rozwojowa. Psychologia dzieci niewidomych i słabo widzacych, Warszawa 2002, passim; M. Czerwińska, Niewidomy, [w:] Encyklopedia pedagogiczna XXI wieku. T. 3, M-O, pod red. T. Pilcha, Warszawa 2004, s. 685-693.

19 Ibidem. 


\section{MATERIAŁY ALTERNATYWNE I TECHNOLOGIE WSPOMAGAJĄCE WE WSPÓŁCZESNEJ BIBLIOTECE}

Współczesny repertuar wydawnictw w tzw. formatach alternatywnych uwzględnia: wydawnictwa w systemie Braille'a; wydawnictwa do odbioru wielozmysłowego (np. obrazkowe książki dotykowe, książki brajlo-drukowe); tyflografikę — książki ilustrowane, mapy, plany, makiety, modele; wydawnictwa w systemie W. Moona; wydawnictwa dźwiękowe (analogowa książka mówiona, Digital Talking Books, talking book, audio book); audiodeskrypcję: audiodeskrybowane filmy fabularne, dokumentalne; audiodeskrypcje do dzieł sztuki; wydawnictwa w druku powiększonym; magnigrafikę; wydawnictwa w zapisie cyfrowym (TXT, RTF, DOC, PDF) i graficznym (DJVU); cyfrowe wydawnictwa dźwiękowo-tekstowe (DAISY - Digital Accessible Information System).

Technologie wspomagające/asystujące, umożliwiające osobom z niepełnosprawnością wzroku dostęp do informacji, obejmują: syntezatory mowy, moduły (programy) udźwiękawiające, ubrajlawiające, udźwiękawiająco-ubrajlawiające, powiększające, powiększająco-udźwiękawiające, urządzenia lektorskie, programy lektorskie, monitory brajlowskie, notatniki brajlowskie (z syntezą mowy i monitorem brajlowskim), interaktywne tablety z modułami dźwiękowymi i dotykowymi, brajlowskie klawiatury komputerowe, drukarki brajlowskie, drukarki 3D, wygrzewarki do tłoczenia tyflografiki, powiększalniki i lupy (elektroniczne), OCR, OBR i programy lektorskie, programy użytkowe, np. do brajlowskiego składu i druku komputerowego, do translacji zapisu nutowego na brajlowską notację muzyczną, brajlowskie maszyny do pisania (mechaniczne i elektroniczne), mówiące słowniki elektroniczne, odtwarzacze książek cyfrowych, dyktafony cyfrowe, organizery, programy udźwiękawiające telefony komórkowe (smartfony).

Wśród obowiązujących formatów alternatywnych szczególne znaczenie ma system Braille'a, tyflografika i audiodeskrypcja. Technika komputerowa zniosła niedoskonałości przypisywane systemowi Braille’a, zmieniając również jego morfologię. W pracy z komputerem system Braille'a stał się tymczasową reprezentacją znaków wyświetlanych na ekranie. Dzięki technologii cyfrowej możliwe jest czytanie systemem Braille'a publikacji przechowywanych na nośnikach cyfrowych, co ma szczególne znaczenie w przypadku wydawnictw wielotomowych. Technika cyfrowa doprowadziła do zmiany w budowie systemu Braille’a - współczesna odmiana systemu EUROBRAILLE (tzw. brajl komputerowy) jest oparta na ośmiopunkcie (dwie kolumny po cztery punkty), przy zachowaniu numeracji podstawowych punktów, jak w brajlu standardowym. Kombinacje punktów w brajlu ośmiopunktowym dają 256 różnych znaków. Brajl ośmiopunktowy umożliwia stworzenie specjalnych znaków do zapisu symboli stosowanych w informatyce oraz obsługę elektronicznych urządzeń brajlowskich, np. monitorów i notatników brajlowskich. System Braille’a, bez względu na jego postać, jest „kluczem” do 
umiejętności samodzielnego czytania i pisania. Pozwala opanować zasady ortografii, interpunkcji, gramatyki. Umożliwia zapoznanie się z rozmieszczeniem tekstu na stronie. W porównaniu z odsłuchiwaniem tekstów umożliwia koncentrację na szczegółach i pełniejsze zrozumienie kontekstu treściowego. Udostępnia różne źródła informacji: tekstowe, matematyczne, muzyczne, informatyczne, tyflograficzne. Zapobiega wtórnemu analfabetyzmowi. Stwarza równe szanse edukacyjne, zawodowe. Pozwala uczestniczyć w życiu społecznym, naukowym, technicznym, kulturalnym ${ }^{20}$.

Zdaniem Marka Jakubowskiego tyflografika to „graficzne odwzorowanie rzeczywistości, użyteczne dla osoby niewidomej lub/i słabowidzącej, wykonane w dostępnej jej konwencji i skali, zredagowane w sposób umożliwiający i ułatwiający odczytanie dotykiem lub/i słabym wzrokiem przekazywanej grafiką informacji" ${ }^{21}$. O jej wartości informacyjnej decyduje prawidłowo przeprowadzona adaptacja grafiki, czyli proces przeredagowania prezentacji płaskiej do postaci odpowiedniej dla niewidomego/słabowidzącego odbiorcy. Polega on na: zmianie konwencji - sposobu przedstawienia (dla niewidomego niezrozumiała jest np. perspektywa zbieżna i rzut ukośny); zmianie skali (powiększenie obrazu czytelnego dla widzących); zmianie poziomu generalizacji — uszczegółowienia (rezygnacja z mniej istotnych treści); podziale treści ilustracji na kilka prezentacji tego samego obiektu, wykonanych w tej samej lub w innej niż oryginał konwencji (np. zastąpienie prezentacji obiektu w rzucie ukośnym przez kilka prezentacji tego obiektu w rzucie prostokątnym, podział treści mapy na kilka map w jednej lub w różnych skalach); zmianie linii, znaków i kolorów oryginalnego rysunku na zróżnicowane linie, faktury powierzchniowe (opracowanie tyflograficzne); poważnym uproszczeniu rysunku do prezentacji czytelnej dotykiem i uzupełnieniu opisem ${ }^{22}$.

Tyflografice przypisuje się istotne miejsce w przestrzeni informacyjnej osoby $\mathrm{z}$ niepełnosprawnością wzroku. Informuje ona bowiem o pojęciach przestrzennych (pojęcia geometryczne i z zakresu orientacji), o kształtach przedmiotów (widok, rzut, rzuty, przekrój), o relacjach przestrzennych między przedmiotami (plan, mapa). Pomaga poznać i zrozumieć oraz odwzorować pojęcia przestrzenne i rzeczywistość materialną, przekazać informacje o obiektach i zjawiskach, które

${ }^{20}$ M. Czerwińska, System Braille’a - rewolucja medialna czy inkluzja społeczna osób z niepetnosprawnościa wzroku?, „Przegląd Biblioteczny” 2015, nr 3, s. 365-381; M. Paplińska, Znaczenie czytania dotykowego i jego charakterystyka a bariery mentalne osób niewidomych i ociemniatych wobec pisma Braille'a, [w:] Pismo Braille'a..., s. 89-100.

${ }^{21}$ M. Jakubowski, Tyflografika — historia i wspótczesność, metody i technologie, „Tyfloświat” 2009, nr 1 (3), s. 36-40; E. Więckowska, Zasady redagowania tyflografiki, „Tyfloświat” 2009, nr 3 (5), s. 7-13.

22 M. Czerwińska, Tyflografika - szansa na nowe oblicze ksiażki niewidomego i obecność jej użytkowników w świecie informacji? W kręgu rozważań bibliologiczno-tyflologicznych, „Przegląd Biblioteczny” 2017, z. 2, s. 169-184. 
nie są możliwe do poznania poprzez bezpośredni ogląd dotykowy (zbyt małe, zbyt delikatne, za duże, niebezpieczne lub poruszają się) $)^{23}$.

Audiodeskrypcja (ad) posiada wiele ujęć definicyjnych. W ustawie o radiofonii i telewizji definiowana jest jako ,werbalny, dźwiękowy opis obrazu i treści wizualnych zawartych $\mathrm{w}$ audycji audiowizualnej przeznaczony dla osób niepełnosprawnych z powodu dysfunkcji narządu wzroku, umieszczony w audycji lub rozpowszechniany równocześnie z audycją" ${ }^{24}$. Twórcy audiodeskrypcji w Polsce, założyciele białostockiej Fundacji „Audiodeskrypcja” — Barbara Szymańska i Tomasz Strzymiński, rozumieją audiodeskrypcję jako przekład treści obrazu na słowa. Werbalny opis warstwy wizualnej spektakli teatralnych, produkcji audiowizualnych, sztuk plastycznych oraz wydarzeń widowiskowych sprawia, iż stają się one dostępne osobom niewidomym i słabowidzącym ${ }^{25}$. Według Anny Jankowskiej i Agnieszki Szarkowskiej jest to szczególna odmiana tłumaczenia audiowizualnego, dzięki której osoby z deficytem wzroku otrzymują dostęp do treści odbieranych przez osoby widzące głównie za pomocą narządu wzroku. Audiodeskrypcja jest zatem narracją, przekładem audiowizualnym, przekładem intersemiotycznym, przekładem wewnątrzjęzykowym ${ }^{26}$.

Wypracowano kilka podstawowych rodzajów audiodeskrypcji:

— audiodeskrypcja w sztukach wizualnych — wykorzystywana w muzeach i galeriach sztuki, zazwyczaj w postaci plików dźwiękowych, dołączanych do przewodników audio; opisuje dzieła z zakresu malarstwa, rzeźby, fotografii czy instalacji; stosowana do opisu architektury, terenu naturalnego;

— audiodeskrypcja na potrzeby ekranu (w filmie, programach telewizyjnych) — występuje jako dodatkowa ścieżka dźwiękowa pomiędzy dialogami; opisywane są w niej elementy wizualne (gra aktorów, kostiumy, barwy i światło, scenografia);

— audiodeskrypcja w przedstawieniach na żywo — w spektaklu teatralnym; odczytywana na żywo, wplatana pomiędzy dialogi aktorów; w operze, na koncertach, na przedstawieniach tanecznych (baletowych);

— audiodeskrypcja widowisk sportowych — różni się od komentarza radiowego szczegółowym opisem lokalizacji zawodników czy opisywaniem tego, co dzieje się na trybunach;

23 Ibidem.

24 Ustawa z dnia 29 grudnia 1992 roku o radiofonii i telewizji, http://www.isap.sejm.gov. pl/DetailsServlet?id=WDU19930070034 [dostęp: 5.05.2017]; Ustawa z dnia 25 marca 2011 roku o zmianie ustawy o radiofonii i telewizji oraz niektórych innych ustaw, http://www.isap.sejm.gov. pl/DetailsServlet?id=WDU20110850459 [dostęp: 20.11.2017].

25 B. Szymańska, T. Strzymiński, Audiodeskrypcja. Obraz słowem malowany. Standardy tworzenia audiodeskrypcji do produkcji audiowizualnych, Białystok 2010, passim.

26 A. Jankowska, Audiodeskrypcja - wzniosty cel w ttumaczeniu, „Między oryginałem a przekładem" 14, 2009, s. 225-246; A. Szarkowska, Przekład audiowizualny w Polsce - perspektywy $i$ wyzwania, „Przekładaniec” 2009, nr 1 (20), s. 8-25. 
- audiodeskrypcja prasowa (ilustracji prasowej) — stosowana w elektronicznej wersji czasopism;

- audiodeskrypcja w materiałach edukacyjnych — stosowana np. w multimedialnych środkach dydaktycznych ${ }^{27}$.

Informacyjna wartość audiodeskrypcji warunkowana jest jej profesjonalnym przygotowaniem, uwzględniającym zasady: należy dokładnie poznać utwór/ obiekt, który będzie opisywany; opis powinien odpowiadać na pytania: kto?, co?, jak?, gdzie?, kiedy?; należy opisywać w myśl zasady — od ogółu do szczegółu; opis ma pobudzać wyobraźnię (używając bogatego słownictwa, porównań, metafor, epitetów); należy zachować obiektywizm (bez wartościowania, komentowania, interpretowania czy cenzurowania); opis musi być spójny, przemyślany i odpowiadać na potrzeby odbiorcy; opis musi być dostosowany do określonej grupy odbiorców, np. dzieci; tekst audiodeskrypcji, przed odtworzeniem przez użytkownika, powinien zostać poddany redakcji i ocenie innego redaktora/ konsultanta; jakość nagrania/odczytania tekstu powinna być bardzo dobra. Prawidłowo przygotowana audiodeskrypcja powinna cechować się zwięzłością (kondensacją), obiektywizmem i neutralnością. Audiodeskrypcja, zrealizowana z poszanowaniem zasygnalizowanych zasad, umożliwia bowiem dostęp do wizualnych i audiowizualnych dóbr kultury, udostępnia edukacyjne produkty audiowizualne (multimedia), dostarcza opisu przedmiotów i zjawisk niemożliwych do poznania dotykowego. Pomaga w przyswajaniu specjalistycznej terminologii związanej z różnymi dziedzinami nauki, umożliwia jej użytkownikom włączanie się samodzielnie, aktywnie i kompetentnie w życie społeczno-kulturalne, inspiruje wrażenia estetyczne, umożliwia doświadczanie piękna ${ }^{28}$.

Wzmiankowane tu wydawnictwa i technologie wspomagające ułatwiają edukację i pracę osób z niepełnosprawnością wzroku, zwiększają możliwości komunikacyjne (w tym komunikację zapośredniczoną) i dostęp do informacji.

Rozwój tyfloinformatyki i tyflologii wskazuje, że w przyszłości nastąpi radykalne ograniczenie wydawania książek w systemie Braille'a. Stosowane one będą jedynie w edukacji wczesnoszkolnej oraz w nauce pisma punktowego. System ten będzie też wykorzystywany do czytania książek elektronicznych. Podstawową formą książki dla niewidomych stanie się książka cyfrowa w różnych formatach (np. DAISY, TXT, HTML, MP3, PDF). Przemawiają za nią m.in.: łatwość jej pozyskiwania, postać pliku lub plików, odtwarzanie na ekranie monitora komputerowego lub w specjalnych urządzeniach lektorskich, dedykowanych użytkownikom z niepełnosprawnością wzroku, możliwość rozszerzenia standardowego komunikatu tekstowego o multimedia, hipertekst, wyszukiwarkę czy własny system nawigacyjny.

27 M. Ciborowski, Znaczenie audiodeskrypcji dla niewidomych w Polsce, „Przekładaniec” 2009, nr 20, s. 136-138.

28 M. Kalbarczyk, J. Mirowski, Świat opisywany dźwiękiem, Warszawa 2015, passim. 
Obecnie, według danych Światowej Unii Niewidomych, tylko 5\% wszystkich wydawanych publikacji jest dostępnych dla osób z niepełnosprawnością wzroku. Szansą na udostępnianie literatury (zwłaszcza naukowej i nowości wydawniczych) jest książka cyfrowa w dostępnych dla niewidomych formatach ${ }^{29}$.

\section{ZASTOSOWANIE TECHNOLOGII CYFROWYCH W BIBLIOTEKACH DLA NIEWIDOMYCH W POLSCE}

W dziejach bibliotek dla osób z niepełnosprawnością wzroku wyróżnia się trzy okresy: okres bibliotek brajlowskich, bibliotek hybrydowych i cyfrowych. Ze względu na przynależność organizacyjną są to biblioteki szkolne, publiczne, organizacji pozarządowych, uniwersyteckie. Pierwsze biblioteki brajlowskie zakładano przy szkołach dla niewidomych na przełomie XVIII i XIX wieku. Książnice publiczne powstawały od końca XIX wieku, np. przy British and Foreign Blind Association (Londyn, 1882), przy Association Valentin Haüy (Paryż, 1884), Deutsche Zentralbücherei für Blinde (Lipsk, 1894), Centralbibliothek für Blinde (Hamburg, 1905), obecna Emil-Krückmann-Bücherei (Marburg, 1916). Z czasem w wielu bibliotekach pojawiły się zbiory książki mówionej, np. w Library of Congress (od 1934), w Marburgu (od 1954 Deutsche Blindenhörbücherei) ${ }^{30}$. W Polsce do 1939 roku największe zbiory brajlowskie posiadały biblioteki: Towarzystwa „Polski Braille” w Warszawie, Towarzystwa Opieki nad Niewidomymi w Bydgoszczy, Związku Ociemniałych Żołnierzy we Lwowie, Towarzystwa Opieki nad Ociemniałymi w Laskach — zasilane przez drukarnie i biura kopistów tych towarzystw. Ze zniszczeń II wojny światowej ocalała tylko część biblioteki w Laskach, stanowiąc największy księgozbiór brajlowski w Polsce (Dział Braille’a), systematycznie pomnażany przez własną produkcję wydawniczą Zakładów dla Niewidomych i Towarzystwa Opieki nad Ociemniałymi ${ }^{31}$.

Biblioteki brajlowskie, coraz intensywniej wzbogacane zasobami multimedialnymi, istnieją w ośrodkach szkolnych i rehabilitacyjnych.

W 1952 roku powstała w Warszawie Biblioteka Centralna Polskiego Związku Niewidomych — BC PZN (od 2013 roku Dział Zbiorów dla Niewidomych Głównej Biblioteki Pracy i Zabezpieczenia Społecznego). W jej strukturze znajdują się obecnie: dział książki mówionej (książki na kasetach magnetofonowych, w formacie MP3, CD-Audio, DAISY typu I i II, cyfrowe książki w plikach teksto-

29 M. Czerwińska, Od Braille’a do DAISY - o czytaniu i czytelnictwie osób z niepetnosprawnościa wzroku, [w:] Czytanie, czytelnictwo, czytelnik, pod red. A. Żbikowskiej-Migoń przy współudziale A. Łuszpak, Wrocław 2011, s. 175-188.

30 Eadem, Biblioteki dla niewidomych, [w:] Encyklopedia książki, pod red. A. ŻbikowskiejMigoń, M. Skalskiej-Zlat, t. 1, Wrocław 2017, s. 304-305.

31 Eadem, Pismo i książka w systemie L. Braille'a w Polsce. Historia i funkcje rewalidacyjne, Warszawa 1999, s. 29-45; Eadem, Biblioteki dla niewidomych..., s. 304. 
wych, książki w plikach tekstowych przetworzone mową syntetyczną do formatu MP3, książki w formacie „Czytak”); dział książek brajlowskich (wydawnictwa zwarte i periodyczne, nuty, podręczniki szkolne); dział zbiorów i informacji tyflologicznej (zwarte i periodyczne wydawnictwa naukowe z zakresu tyflologii i nauk pokrewnych); filmy z audiodeskrypcją; dział zbiorów muzycznych (nagrania na różnych nośnikach muzyki klasycznej i rozrywkowej); tyflogaleria (pomoce rehabilitacyjne, twórczość artystyczna niewidomych i słabowidzących). Całość zbiorów ujęta jest w katalogach dostępnych online. Serwisy i zasoby sieciowe BC PZN obejmują: serwis wypożyczeń online, archiwum elektronicznych czasopism dla niewidomych, bibliografię zawartości czasopism tyflologicznych, listy dyskusyjne dla czytelników i bibliotekarzy, wirtualne muzeum tyflologiczne. Dostępne są również usługi i urządzenia: skanowanie książek na zamówienie czytelników, drukowanie prostych tekstów brajlowskich na indywidualne potrzeby czytelników, kody PIN do platformy IBUK Libra Light, udostępniające użytkownikom niewidzącym publikacje $\mathrm{w}$ formatach EPUB i MP3, odtwarzacz audio online, dostęp do zasobów bibliotek dla niewidomych na całym świecie — projekt TIGAR (Trusted Intermediaries Global Accessible Resources) ${ }^{32}$.

Od 1976 roku obsługą osób z niepełnosprawnością wzroku zaczęły zajmować się biblioteki publiczne (działy, oddziały, filie dla osób niepełnosprawnych). Udostępniają analogową i cyfrową książkę mówioną, podejmują różne formy pracy z czytelnikiem (np. kluby dyskusyjne książki mówionej). W przeciwieństwie do praktyki w krajach zachodnich (np. Kanada, USA, W. Brytania, Dania) działalność ta nie jest skoordynowana - brak np. centralnego katalogu zbiorów w formatach alternatywnych.

W Rozporządzeniu Ministra Pracy i Polityki Społecznej oraz Ministra Kultury i Dziedzictwa Narodowego z dnia 6 września 2013 roku w sprawie wykazu bibliotek, organizacji osób niewidomych lub ociemniałych oraz organizacji, których celem statutowym jest działanie na rzecz osób niewidomych lub ociemniałych, wymienia się 18 bibliotek publicznych ${ }^{33}$. Analiza ich witryn internetowych (w tym roczne sprawozdania z działalności merytorycznej) wskazuje, że główną formą działalności jest udostępnianie książek w systemie Braille’a i tzw. książek mówionych (na kasetach magnetofonowych, w znacznie mniejszym zakresie na nośnikach CD i w formacie MP3).

Biblioteki udostępniają tzw. „Czytak” (odtwarzacz cyfrowych książek mówionych) oraz Auto-Lektora (urządzenie czytające głosem syntetycznym pismo drukowane). Standardem są również komputery z dostępem do Internetu wraz $\mathrm{z}$ odpowiednim oprogramowaniem typu screen reader.

32 Eadem, Biblioteki dla niewidomych..., s. 305; Dział Zbiorów dla Niewidomych, Główna Biblioteka Pracy i Zabezpieczenia Społecznego [serwis internetowy], http://www.dzdn.pl/ [dostęp: 20.11.2017].

33 www.dziennikustaw.gov.pl/du/2013/1120/D2013000112001.pdf [dostęp: 20.11.2017]. 
Stąd też niezwykle cenne jest przedsięwzięcie Wojewódzkiej i Miejskiej Biblioteki Publicznej im. C. Norwida w Zielonej Górze - oprogramowanie SUZI, umożliwiające czynne korzystanie $\mathrm{z}$ typowych i innych nowoczesnych e-usług, np. dostęp do audiobooków, e-booków, korzystanie z kursów i szkoleń w ramach systemu e-learningowego, dostęp do elektronicznej platformy przeznaczonej dla artystów, sprawdzenie wszystkich aktualnych wydarzeń organizowanych w Bibliotece, w mieście i regionie, dostęp do wideokonferencji i wirtualnych spotkań, bezpośrednie skontaktowanie się z bibliotekarzem. Projekt „Nowoczesne e-usługi w WiMBP" uwzględnia w swoich założeniach potrzeby czytelników niepełnosprawnych wzrokowo (możliwość przełączenia się na tryb tekstowy o wysokim kontraście z opcją powiększania czcionki, zoptymalizowany także pod usługę WebReader - pozwalającą odczytać treść strony internetowej przez syntezator mowy).

Udostępniane są czytniki „e-clicto” e-booków i odtwarzacz cyfrowych książek mówionych „Czytak Plus”. Świadczona jest również usługa digitalizacji na żądanie. W 2015 roku opracowano koncepcję oraz przygotowano wniosek o dofinansowanie projektu „E-Biblioteka Norwida przyjazna osobom z niepełnosprawnością i wykluczonym cyfrowo", mającego na celu m.in.: umożliwienie oraz ułatwienie korzystania z e-zasobów WiMBP (zarówno lokalnych, jak i udostępnianych zdalnie) osobom z niepełnosprawnością poprzez przebudowę, aktualizację oraz dostosowanie do spełnienia standardu WCAG 2.0 na poziomie A i AA wszystkich udostępnianych przez WiMBP serwisów internetowych, baz danych oraz nowoczesnych e-usług; przygotowanie infrastruktury pozwalającej na zdalny dostęp do specjalistycznego oprogramowania umożliwiającego korzystanie z zasobów informacyjnych, również innych niż należące do WiMBP, dla osób z niepełnosprawnością, nieposiadających dostosowanego sprzętu komputerowego i jednocześnie niemogących opuszczać miejsca zamieszkania; poszerzenie zakresu udostępnianych zasobów o treści dedykowane dla środowiska osób $\mathrm{z}$ niepełnosprawnością, $\mathrm{w}$ tym dostęp do nieodpłatnych zewnętrznych specjalistycznych baz danych z zakresu szeroko pojętych zagadnień niepełnosprawności, rynku pracy dla osób z tej grupy, dedykowanej oferty (np. turystycznej czy rehabilitacyjnej); przygotowanie stanowisk komputerowych dodatkowo wyposażonych w specjalistyczne urządzenia i oprogramowanie dedykowane dla osób z niepełnosprawnością ${ }^{34}$.

Wśród bibliotek akademickich od 1997 roku wiodącą rolę pełni Biblioteka Uniwersytetu Warszawskiego (BUW), m.in. prowadząc Bibliotekę Książek Cy-

34 Informacja z działalności Wojewódzkiej i Miejskiej Biblioteki Publicznej im. C. Norwida w Zielonej Górze za 2015 rok, Zielona Góra 2016, plik elektroniczny, archiwum autorki; Informacja z działalności Wojewódzkiej i Miejskiej Biblioteki Publicznej im. C. Norwida w Zielonej Górze za 2016 rok, Zielona Góra 2017, plik elektroniczny, archiwum autorki. 
frowych, przygotowując materiały w formatach alternatywnych na zamówienie użytkownika, posiadając tyfloinformatyczne kabiny do pracy indywidualnej ${ }^{35}$.

Pierwsza w Polsce biblioteka cyfrowa dla niewidomych powstała w 2010 roku, z inicjatywy Biblioteki Uniwersytetu Warszawskiego - Akademicka Biblioteka Cyfrowa (ABC), prowadzona wspólnie przez czołowe uczelnie Polski. Jest platformą wymiany informacji o zaadaptowanych materiałach, internetowym centrum materiałów dydaktycznych w postaci biblioteki cyfrowej dla studentów niepełnosprawnych. Zbiory obejmują: książki, czasopisma i inne dokumenty (konspekty, prezentacje, materiały niebędące książką ani czasopismem) —o różnych kategoriach adaptacji: skan z korektą, skan bez korekty, skan z adaptacją $i$ adaptacja audio (format DAISY lub MP3).

Każdy zbiór, bez względu na użyty format dokumentu, jest tak przygotowany, aby był dostępny dla programów odczytu ekranu i specjalistycznych urządzeń lektorskich. Czytelnicy pobierają biblioteczne zbiory na swój komputer. Opisy bibliograficzne i system haseł przedmiotowych został zaczerpnięty z Biblioteki Narodowej. ABC znamionuje: zwielokrotnienie zbiorów przez współpracę, współpraca w rozproszeniu, katalog centralny, łatwość przeszukiwania zbiorów, respektowanie zasad dostępności, łatwość rozbudowy ${ }^{36}$.

E-kiosk jest biblioteką czasopism w formatach dostępnych dla niewidomych, prowadzoną przez Mazowieckie Stowarzyszenie Pracy dla Niepełnosprawnych „De Facto”. Czasopisma są konwertowane do formatu cyfrowego, dostępnego dla technologii wspomagających, zawierają opisy materiałów graficznych (np. zdjęcia, wykresy) ${ }^{37}$.

Biblioteka Uniwersytetu Zielonogórskiego zainicjowała w 2011 roku tworzenie wydzielonej kolekcji zbiorów cyfrowych dla niewidomych według obowiązujących sylabusów przedmiotów studiów, wprowadzając ją w środowisko dLibra, zapoczątkowując tym samym tworzenie dużego warsztatu naukowo-dydaktycznego dla niewidomych studentów i pracowników naukowych z całej Polski ${ }^{38}$. Zielonogórska Biblioteka Cyfrowa dla Osób Niewidomych liczy ponad 200 publikacji naukowych i dydaktycznych (w plikach PDF, poddanych technikom OCR) i jest

35 M. Czerwińska, Biblioteki dla niewidomych..., s. 305; Biblioteka Uniwersytecka w Warszawie [serwis internetowy], http://www.buw.uw.edu.pl/informacje-praktyczne/buw-bez-barier/ [dostęp: 20.11.2017].

36 Akademicka Biblioteka Cyfrowa [serwis internetowy], http://www.abc.uw.edu.pl [dostęp: 20.11.2017].

37 E-kiosk Mazowieckiego Stowarzyszenia Pracy dla Niepełnosprawnych „De Facto”, Internetowy serwis z prasą dla osób niewidomych i słabowidzących [serwis internetowy], http://www. ekiosk2.defacto.org.pl/ [dostęp: 20.11.2017].

38 Zielonogórska Biblioteka Cyfrowa dla Niewidomych [serwis internetowy], zbc.uz.zgora. $\mathrm{pl} / \mathrm{dlibra} /$ collectiondescription?dirids=684 [dostęp: 15.10.2017]. 
systematycznie powiększana. Jest to pierwsza biblioteka cyfrowa dla niewidomych w oprogramowaniu dLibra i jedna z nielicznych w kraju ${ }^{39}$.

Biblioteka Uniwersytetu Zielonogórskiego dysponuje programami udźwiękawiającymi dla osób niewidomych, profesjonalnym narzędziem do tworzenia plików DjVu i rozpoznania znaków (OCR) oraz specjalistycznym oprogramowaniem odczytującym dokumenty. Ma też bazę szkoleniowo-edukacyjną, warsztat pracy dla redaktorów obsługujących bibliotekę cyfrową ze specjalistycznym oprogramowaniem do pełnej obróbki plików cyfrowych, oprogramowanie graficzne, do kompresji obrazu, do tworzenia i odtwarzania plików w formacie DAISY oraz programy do tworzenia dokumentów publikowanych w bibliotekach cyfrowych. Strona internetowa Biblioteki jest zgodna z wymogami WCAG $2.0^{40}$.

\section{ZAKOŃCZENIE}

Znaczenie podjętych tu rozważań dla nauk bibliologicznych (rola współczesnej biblioteki w kształtowaniu kultury informacji i czytelniczej użytkowników niepełnosprawnych wzrokowo) i dla nauk tyflologicznych (nowoczesna edukacja i rehabilitacja niepełnosprawnych wzrokowo dzieci, młodzieży i dorosłych) znajduje potwierdzenie w wynikach ogólnopolskich badań nad uczestnictwem osób z dysfunkcją wzroku w kulturze, zrealizowanych w latach 2015-2017 ${ }^{41}$. Wskazują one, że czytanie książek lokuje się na pierwszym miejscu wśród sposobów wypełniania wolnego czasu.

Przeczytanie co najmniej jednej książki w okresie ostatniego roku deklaruje ok. 92\% osób niewidomych w wieku powyżej 16 lat. Według badania Biblioteki Narodowej analogiczny wskaźnik dla ogółu Polaków w wieku 15+ wyniósł w 2014 roku jedynie ok. $43 \%{ }^{42}$.

Według tego samego badania odsetek Polaków, którzy przeczytali w 2014 roku 7 książek lub więcej, wyniósł 11\%, podczas gdy w grupie osób z dysfunkcją wzroku - ok. 66\% deklaruje przeczytanie 10 i więcej książek rocznie. Około jednej trzeciej grupy niewidzących czytelników książek deklaruje czytanie 50 i więcej książek rocznie. A zatem poziom czytelnictwa wśród osób z niepełnosprawnością wzroku jest znacząco wyższy niż w populacji generalnej. Wysoki poziom czytelnictwa wśród osób niepełnosprawnych wzrokowo jest wynikiem przede wszystkim rewolucji tyfloinformatycznej, czyniącej książki bardziej dostępnymi.

39 Sprawozdanie z działalności Biblioteki Uniwersytetu Zielonogórskiego za lata 2015/2016, Zielona Góra 2017, plik elektroniczny, archiwum autorki.

40 Ibidem.

41 http://www.kulturaslepych.farbb.com/ [dostęp: 20.11.2017].

42 Raport: Stan czytelnictwa w Polsce w 2014 roku - Biblioteka Narodowa, www.bn.org.pl/ download/document/1428654601.pdf [dostęp: 20.11.2017]. 
Preferowanymi sposobami czytania książek są: książki mówione nagrane przez lektora $(72,2 \%)$, książki elektroniczne czytane przez syntezator mowy $(45,2 \%)$, książki brajlowskie papierowe (10,6\%), książki papierowe w druku powiększonym $(9,0 \%)$, książki papierowe czytane przy użyciu urządzeń powiększających (7,6\%), książki czytane przez lektora (3,5\%), książki elektroniczne czytane przy pomocy monitora brajlowskiego $(3,5 \%)$.

Według badania Biblioteki Narodowej analogiczny wskaźnik czytania audiobooków wśród Polaków w wieku 15+ wyniósł w 2014 roku 21\%, a dla e-booków - $12 \%$. Czytanie periodyków deklaruje ok. $41 \%$ ogółu niewidzących respondentów. $66,3 \%$ ogółu osób czytających gazety i/lub czasopisma czyta je w formie elektronicznej, specjalnie opracowanej dla osób niewidomych. 21,5\% czyta zwykłe wydania papierowe, wspomagając się urządzeniami powiększającymi, 13,5\% czyta wydania elektroniczne prasy przeznaczone dla ogółu czytelników, 8,0\% czyta czasopisma papierowe drukowane brajlem, 6,7\% zapoznaje się z czasopismami za pośrednictwem lektora. Dla ogółu Polaków w wieku 15+ odsetek czytających periodyki wyniósł w 2014 roku 74\%. Poziom czytelnictwa czasopism i prasy codziennej jest więc w środowisku osób niepełnosprawnych wzrokowo wyraźnie niższy niż w populacji pełnosprawnych Polaków.

Przytoczone tu dane pozostawiają aktualnymi wytyczne IFLA dla bibliotek obsługujących użytkowników z niepełnosprawnością wzroku: ścisła kooperacja bibliotek centralnych dla niewidomych z bibliotekami publicznymi, innymi rodzajami bibliotek oraz placówkami edukacyjnymi, organizacjami charytatywnymi, wydawcami; przygotowywanie (także na zamówienie klienta), gromadzenie i udostępnianie materiałów w formatach alternatywnych, ich wymiana międzybiblioteczna; digitalizacja zbiorów analogowej książki mówionej; współpraca z wydawcami e-booków (np. pełnotekstowe bazy danych, wydawnictwa informacyjne, periodyki) w celu przygotowywania ich zgodnie $\mathrm{z}$ wymogami technologii wspomagających, tworzenie katalogów (baz danych) o zasobach i ich formatach ${ }^{43}$.

Postulować należy również powoływanie w bibliotekach koordynatorów ds. obsługi biblioteczno-informacyjnej osób z niepełnosprawnością (także wzroku), współpracujących z organizacjami pozarządowymi osób niepełnosprawnych.

Wyzwanie technologiczne (także dla bibliotek) w dziedzinie dostępu do książek stanowią nadal wydawnictwa specjalistyczne, jak podręczniki do nauki języków obcych, wydawnictwa zawierające zapis matematyczny, chemiczny lub fizyczny oraz wydawnictwa nutowe. Publikacje tego rodzaju wymagają nadal żmudnych ręcznych prac udostępniających i nie dają się czytać przy pomocy ist-

43 Libraries for the Blind in the Information Age - Guidelines for development...; Guidelines for Library Service to Braille Users...; IFLA Manifesto for libraries serving persons with a print disability, IFLA [serwis internetowy], http://www.ifla.org/publications/ifla-manifesto-forlibraries-serving-persons-with-a-print-disability [dostęp: 15.07.2017]. 
niejącej technologii natychmiast po zakupie, jak ma to miejsce w przypadku e-booków.

Dalsze dociekania badawcze oraz rozstrzygnięcia praktyczne odnoszące się do miejsca materiałów alternatywnych i technologii wspomagających dla osób z niepełnosprawnością wzroku we współczesnej bibliotece można oprzeć na koncepcji dyskursów, zaproponowanej przez E. Śmiechowską, a odnoszących się do uprzystępniania niewidomym wizualnych dzieł sztuki ${ }^{44}$.

Dyskurs obywatelski - oparty na rozwiązaniach prawnych odnoszących się do prawa osób z niepełnosprawnością wzroku do dostępu do informacji i dóbr i instytucji kultury oraz obowiązku władz co do realizacji tych praw - musi się toczyć w duchu społecznego modelu niepełnosprawności. Dyskurs edukacyjny - służący wypracowywaniu sposobów udostępniania informacji i dóbr kultury osobom z niepełnosprawnością wzroku — ma za punkt odniesienia znajomość specyfiki procesów poznawczych i funkcjonowania osób niewidomych i słabowidzących. Dyskurs translatoryjny związany jest z rozumieniem tworzenia dostępnych form dzieł wizualnych dla osób niewidomych i słabowidzących w kategoriach adaptacji (przekodowanie treści wzrokowych na dotykowe i słuchowe bez ingerowania $\mathrm{w}$ ich zawartość informacyjną — np. adaptacja materiałów czytelniczych, przestrzeni fizycznej) i przekładu intersemiotycznego (,przetłumaczenie" istoty dzieła wizualnego na znaki należące do odmiennego systemu semiotycznego, znajdowanie takich sposobów wyrażania, które umożliwią transpozycję sensu i idei zawartych w oryginalnym przekazie). Dyskurs ten odnosi się do audiodeskrypcji i tyflografiki, a jego podstawą jest wiedza na temat budowy dzieła i wpisanych w nie znaczeń. Dyskurs estetyczny koncentruje się na zagadnieniu, czy materiał alternatywny, będący przekładem intersemiotycznym, może mieć wartości estetyczne, czy też skoncentrowany jest wyłącznie na walorach poznawczych. Istotą jest tu wiedza o specyfice (strukturze) przeżyć estetycznych człowieka i źródeł ich wywoływania).

W świetle powyższych rozważań należy stwierdzić, że problematyka materiałów alternatywnych i technologii wspomagających jest doniosłym społecznie wyzwaniem teoretycznym i praktycznym o charakterze interdyscyplinarnym.

${ }^{44}$ E. Śmiechowska-Petrovskij, Kultura haptyczno-werbalna. Osoby niewidzace a sztuki wizualne - między doświadczeniem poznawczym i estetycznym, [w:] K. Krawiecka, E. Śmiechowska-Petrovskij, M. Żelazkowska, Sztuka/twórczość dostępna. Osoby z niepetnosprawnościami i choroba psychiczna w kręgu recepcji i ekspresji sztuki, Warszawa 2016, s. 57-126. 


\section{MALGORZATA CZERWIŃSKA}

\section{FROM A BRAILLE TO A DIGITAL LIBRARY, I.E. ON ALTERNATIVE MATERIALS \\ AND TECHNOLOGICAL AIDS FOR USERS WITH VISUAL IMPAIRMENTS. REFLECTIONS ON BIBLIOLOGY AND VISUAL IMPAIRMENT}

\section{Summary}

Among groups in society at risk of digital exclusion are people with visual impairments. Yet new technologies expand access to information for the visually impaired; they reduce or even eliminate their reading disability and introduce the visually impaired to information culture.

However, this has to be based on a possibility, enshrined in law, of using various materials in alternative formats and with the help of technology.

The present paper, based an analysis of documents and participant observation, examines questions concerning key legal solutions regulating access of people with visual impairments to sources of information, and information and communication technologies, as well as the specificity of the cognitive process of behaviour of visually impaired users. The author presents alternative formats of library material and supporting technologies, particularly modern (digital) version of the Braille system, tactile graphics and audio description. She also examines the evolution of libraries for the blind. The paper ends with suggestions concerning libraries for visually impaired users and well as proposal of research discourses.

KEY WORDS: visually impaired individual, libraries for the blind, alternative format materials, supporting technologies, Braille system, tactile graphics audio description 